Dinamika Sosial Budaya, Vol 19, No. 2, Desember 2017, pp 178-190

p-ISSN: 1410-9859\& e-ISSN: 2580-8524

http://journals.usm.ac.id/index.php/jdsb

\title{
PEMAHAMAN SISTEM PENGENDALIAN INTERN, ASIMETRI INFORMASI, KOMPENSASI DAN KENDALI RELIGIUS TERHADAP PENGUNGKAPAN \\ FRAUD AKUNTANSI OLEH AKUNTAN PUBLIK
}

\author{
Abdul Manan \\ Program Studi Akuntansi, Fakultas Ekonomi, Universitas Semarang, \\ ham11smg@gmail.com \\ Windasari Rahmawati \\ Program Studi Akuntansi, Fakultas Ekonomi, Universitas Semarang, \\ windasarirachmawati@yahoo.com \\ Nasron Alfianto \\ Program Studi Akuntansi, Fakultas Ekonomi, Universitas Semarang, \\ nasron.alfianto@gmail.com
}

\begin{abstract}
Abstrak
Fraud akuntansi sebuah fenomena yang selama ini belum bisa dideteksi oleh akuntan publik sebagai pihak yang memeriksa laporan keuangannya. Terbaru Penipuan dalam bidang akuntansi kembali terjadi di perusahaan raksasa dan tidak terlacak oleh akuntan external (akuntan publik). Awal semester pertama 2017 telah muncul isu terjadinya fraud akuntansi di British Telecom. Pada salah satu anak usahanya di Italia. Kantor akuntan publik yang melakukan pekerjaan audit pada British Telecom bukan kantor akuntan pubik yang kecil tetapi salah satu dari the bigfour, Price Waterhouse Coopers $(P w C)$.Modus fraud akuntansi yang dilakukan British Telecom di Italia sebenarnya relatif sederhana dan banyak dibahas di literatur kuliah auditing namun banyak auditor gagal mendeteksinya. Untuk mengetahui adanya fraud akuntansi auditor berupaya memahami tatakelola perusahaan dan pengetahuan terhadap akuntansi forensik yang memadai. Dalam penelitian ini variabel akuntansi forensik, sistem pengendalian intern, asimetri informasi, kompensasi dan kendali religius sebagai variabel yang digunakan untuk mendeteksi dan memahami ada tidaknya fraud akuntansi pada perusahaan yang di audit oleh auditor.
\end{abstract}

Kata Kunci: Akuntansi forensik, Fraud akuntansi, sistem pengendalian intern.

\begin{abstract}
Fraud accounting a phenomenon that has not been detected by a public accountant as a party that checks its financial statements. Latest Fraud in the field of accounting re-occur in the giant company and not tracked by an external accountant (public accountant). The beginning of the first half of 2017 has emerged the issue of accounting fraud in British Telecom. On one of its subsidiaries in Italy. The public accounting firm doing the audit work on British Telecom is not a small public accounting firm but one of the bigfour, Price Waterhouse Coopers (PwC). The British Telecom accounting fraud mode in Italy is actually relatively simple and much discussed in the literature of auditing lectures yet many auditors fail to detect it. To know the existence of accounting fraud the auditor seeks to understand corporate governance and knowledge of forensic accounting is adequate. In this study, forensic accounting variables, internal control system, information asymmetry, compensation and religious control as variables used to detect and understand the presence or absence of accounting fraud in the company audited by the auditor.

Keywords: Forensic accounting, accounting fraud, internal control system.
\end{abstract}


Dinamika Sosial Budaya, Vol 19, No. 2, Desember 2017, pp 178-190

p-ISSN: $1410-9859 \&$ e-ISSN: 2580-8524

http://journals.usm.ac.id/index.php/jdsb

\section{PENDAHULUAN}

Penipuan dalam bidang akuntansi

kembali terjadi di perusahaan raksasa dan tidak terlacak oleh akuntan external (akuntan publik).Awal semester pertama 2017 telah muncul isu terjadinya fraud akuntansi di British Telecom.Perusahaan raksasa Inggris ini mengalami fraud akuntansi di salah satu lini usahanya di Italia.Sebagaimana skandal fraud akuntansi lainnya, fraud di British Telecom berdampak kepada akuntan publiknya. Tidak tanggung-tanggung, kali ini yang terkena dampaknya adalah Price Waterhouse Coopers (PwC) yang merupakan akuntan publik klien dari British Telecom, dan juga merupakan kantor akuntan ternama di dunia dan termasuk dalam the bigfour. Jauh sebelum itu kasus fraud sudah sering terjadi, belum lupa dari ingatan kita bagaimana kasus Enron yang menguncang dunia, tentu saja dampak fraud akuntansi ini bukan saja menyebabkan reputasi kantor akuntan publik tersebut tercemar, namun ikut mencoreng profesi akuntan publik. Padahal eksistensi akuntan publik sangat tergantung pada kepercayaan publik kepada reputasi profesional akuntan publik.British Telecom mengganti PwC dengan KPMG, kantor akuntan yang berpusat di Belanda. Dan KPMG juga merupakan kantor akuntan yang masuk dalam the bigfour.

Modus fraud akuntansi yang dilakukan British Telecom di Italia sebenarnya relatif sederhana dan banyak dibahas di literatur kuliah auditing namun banyak auditor gagal mendeteksinya. Yaitu mereka para pembuat laporan keuangan melakukan inflasi (peningkatan) atas laba perusahaan selama beberapa tahun dengan cara tidak wajar melalu kerja sama koruptif dengan klien-klien perusahaan dan jasa keuangan. Modusnya adalah membesarkan penghasilan perusahaan melalui perpanjangan kontrak yang palsu dan invoice-nya serta transaksi yang palsu dengan vendor.Praktik fraud ini sudah terjadi sejak tahun 2013.Dorongan untuk memperoleh bonus (tantiem) menjadi stimulus fraud akuntansi ini.

Untuk meminimalkan fraud akuntansi ini perusahaan harus memperhatikan tata kelolanya. Sistem manajemen kinerja yang sehat dan wajar adalah bagian dari tata kelola perusahaan yang baik.Pada beberapa kasus, dorongan untuk memperoleh bonus (tantiem) menjadi stimulus fraud akuntansi ini.Biasanya bonus diukur dari kinerja keuangan dan kinerja itu diukur dari pelampauan atas indikator laba dan aset yang telah ditentukan. Sehingga untuk menilai suatu korporasi (corporate value) oleh investor dan kreditor semestinya harus mengevaluasi desain dan keefektifan tata kelolanya. Value suatu organisasi mestinya tidak hanya mengacu pada kinerja keuangan.Publik tidak bisa mengandalkan akuntan publik untuk mendeteksi fraud dalam penugasannya melakukan audit atas laporan keuangan dikarenakan karakteristik fraud yang selalu disembunyikan dan ditutupi, adanya informasi asimetri, dan groupthink yang kohesif melindungi perbuatan tidak etis, serta kelemahan bawaan atau keterbatasan sistem pengendalian intern untuk mencegah fraud apabila terjadi kolusi dan pengabaian kontrol oleh eksekutif itu sendiri.

Di Indonesia pada medio 2016 laporan OJK (Otoritas Jasa Keuangan), melaporkan banyaknya kasus fraud di dunia perbankan. Menurut OJK paling tidak ada 108 kasus tentang fraud yang ada di dalam industri perbankan. 
Dinamika Sosial Budaya, Vol 19, No. 2, Desember 2017, pp 178-190

p-ISSN: 1410-9859\& e-ISSN: 2580-8524

http://journals.usm.ac.id/index.php/jdsb

Akuntan publik bukan seorang fraud investigator. Meskipun akuntan publik diberikan pengetahuan dan pelatihan tentang fraud, bukan berarti mereka memiliki keahlian yang sama dengan fraud investigator. Pengetahuan dan keahlian auditor intern pun tidak sama dengan orang yang spesialis antifraud atau menjadi investigator fraud.

\section{Perumusan Masalah}

Dari beberapa kasus tentang fraud akuntansi tidak ada kecurangan akuntansi yang dilakukan oleh manajemen terdeteksi oleh akuntan atau auditor external sewaktu pelaksanaan audit dilakukan. Pertanyaan penelitian ini dirumuskan sebagai berikut; Bagaimana pengaruh pemahaman akuntansi forensik terhadap kendali religius, bagaimana pengaruh sistem pengendalian intern terhadap kendali religius, bagaimana pengaruh Asimetri informasi terhadap kendali religius, bagaimana pengaruh kompensasi terhadap kendali religius, bagaimana pengaruh kendali religius terhadap pengungkapan fraud akuntansi.

\section{TELAAH PUSTAKA}

\section{Landasan Teori}

\section{Strain Theory (Means - Ends Scheme)}

"Individu-individu dari kelas sosial rendah menjadi frustasi oleh ketidakmampuannya untuk beradaptasi dalam anugerah ekonomi masyarakat yang lebih luas, akan mengarahkan kembali energi mereka ke dalam kegiatan kriminal sebagai suatu cara untuk memperoleh anugerah ini" (Merton, 1957)

Strain Theoryatau Teori Ketegangan,memiliki fokus terhadap suatu konflik antara tujuan dan cara-cara yang digunakan untuk mencapai tujuan tersebut. Struktur sosial merupakan akar dari masalah kejahatan, karena itu pendekatan Strain Theory kadang disebut a structuralexplanation. Berasumsi bahwa pada dasarnya orang itu taat hukum, tetapi dibawah tekanan besar mereka akan melakukan kejahatan, disparitas antara tujuan dan sarana iniliah yang memberikan tekanan. Ketika semua orang bergiat untuk mencapai kesuksesan, orang yang paling tidak mungkin sukses melalui cara-cara yang sah adalah yang paling tertekan untuk (terpaksa) mempergunakan kesempatan yang ilegal atau caracara yang tidak sah.

Robert K. Merton (1957) mengemukakan teorinya bahwa korupsi merupakan suatu perilaku manusia yang diakibatkan oleh tekanan sosial, sehingga menyebabkan pelanggaran norma-norma. Setiap sistem sosial memiliki tujuan dan manusia berusaha untuk mencapainya melalui cara-cara (means) yang telah disepakati.Teori Strain (Means-Ends Scheme) dari Merton ini ditujukan untuk menjawab bagaimana kebudayaan terlalu menekankan sukses ekonomi tetapi membatasi kesempatan-kesempatan untuk mencapainya yang akan menyebabkan tingkat korupsi yang tinggi. Suatu kehidupan masyarakat yang mementingkan anggota keluarga sendiri (nepotisme) maupun kepentingan antar individu dan kelompok (kolusi), akan menyebabkan orang lain iri dan menyuburkan korupsi. Demikian pula orang akan mencari jalan di dalam mencapai struktur kekuasaan agar ia mendapatkan kesempatan untuk memperoleh apa yang diinginkannya. Hal ini dapat menjelaskan mengapa banyak negara berkembang jatuh ke dalam wabah korupsi.

\subsubsection{Fraud}

Dalam istilah sehari-hari fraud sering diberi nama yang berlainan, seperti pencurian, 
Dinamika Sosial Budaya, Vol 19, No. 2, Desember 2017, pp 178-190

p-ISSN: $1410-9859 \&$ e-ISSN: 2580-8524

http://journals.usm.ac.id/index.php/jdsb

penyerobotan, pemerasan, pengisapan, penggelapan, pemalsuan, dan lain-lain. Sesuai dengan Pernyataan Standar Auditing (PSA) No. 70, Fraud diterjemahkan sebagai kecurangan, sedangkan error dan irregularities masing-masing diterjemahkan sebagai kekeliruan dan ketidakberesan sesuai PSA sebelumnya yaitu PSA No.32. Fraud dapat diklasifikasikan menjadi tiga macam menurut Association of Certified Fraud Examinations (ACFE) yaitu:

1. Kecurangan Laporan Keuangan (Financial Statement Fraud). Fraud yang dilakukan oleh manajemen yaitu dalam bentuk salah saji material laporan keuangan yang merugikan investor dan kreditor yang bersifat finansial atau non finansial.

2. Penyalahgunaan Aset (Asset Misappropriation). Penyalahgunaan asset dapat digolongkan ke dalam 'kecurangan kas' dan kecurangan atas persediaan dan aset lainnya, serta fraudulent disbursement.

3. Korupsi (Corruption). Korupsi terjadi apabila memenuhi tiga kriteria yang merupakan syarat bahwa seseorang bias dijerat undangundang korupsi, yaitu: melawan hukum, memperkaya diri sendiri atau orang lain atau korporasi, merugikan keuangan negara atau perekonomian negara.

\section{Fraud Triangle Theory}

Donald R. Cressey (1953), mengungkapkan konsep fraud yang dikenal dengan fraud triangle atau segi tiga fraud. Cressey menyatakan alasan seseorang melakukan fraud, yaitu karena disebabkan oleh adanya :

1. Tekanan (pressure), untuk melakukan kecurangan lebih banyak tergantung pada skondisi individu, seperti sedang menghadapi masalah keuangan, kebiasaan buruk seseorang seperti berjudi dan peminum; tamak atau mempunyai harapan/ tujuan yang tidak realistik.

2. Kesempatan (opportunity), menurut penelitian yang dilakukan oleh IIA Research Foundation tahun 1984, dengan urutan paling sering terjadi.

3. Pembenaran (rationalization), terjadi dalam hal seseorang atau sekelompok orang membangun pembenaran atas kecurangan yang dilakukan.

\section{Fraud Diamond}

Kecurangan atau fraud didefinisikan oleh G. Jack Bologna, Robert J.Lindquist dan Joseph T.Wells (1993) sebagai berikut: “ Fraud is criminal deception intended to financially benefit the deceiver". Kecurangan adalah penipuan kriminal yang bermaksud untuk memberi manfaat keuangan kepada si penipu. Kriminal disini berarti setiap tindakan kesalahan serius yang dilakukan dengan maksud jahat. Fraud diamond merupakan sebuah pandangan baru tentang fenomena fraud yang dikemukakan oleh Wolfe dan Hermanson (2004). Fraud diamond merupakan suatu bentuk penyempurnaan dari teori Fraud Triangle oleh Cressey (1953). Selain elemen tekanan (pressure), kesempatan (opportunity), dan rasionalisasi, Wolfe dan Hermanson (2004) menambahkan satu elemen kualitatif yang diyakini memiliki pengaruh signifikan terhadap fraud yakni kemampuan (capability) sehingga menjadi empat elemen yang dikenal dengan Fraud Diamond. Menurut Hay (2013) dalam Shelton (2014), capability adalah sifat dari individu yang melakukan penipuan/ fraud, yang mendorong mereka untuk mencari kesempatan dan memanfaatkannya untuk 
Dinamika Sosial Budaya, Vol 19, No. 2, Desember 2017, pp 178-190

p-ISSN: $1410-9859 \&$ e-ISSN: 2580-8524

http://journals.usm.ac.id/index.php/jdsb

melakukan kecurangan. Dalam penelitian ini, elemen capability diproksikan dengan variabel posisi/ jabatan dalam pekerjaan, level penalaran moral, dan kompetensi, sebagaimana di gambarkan berikut ini:

\section{Fraud Diamond}

Incentive Perceived Opportunity

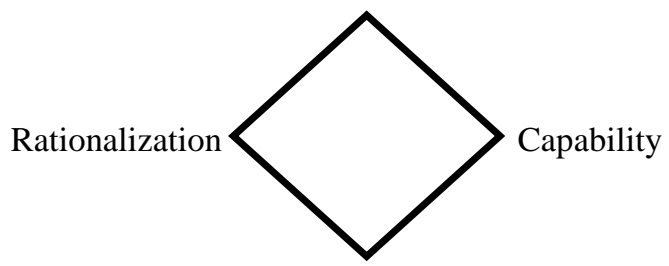

Gambar:Fraud Diamond - Wolfe and Hermanson

Fraud merupakan tindakan yang jelas-jelas bertentangan dengan nilai-nilai dalam masyarakat karena tindak fraud menimbulkan banyak kerugian baik secara materiil maupun moril, misalnya hancurnya reputasi organisasi, kerugian organisasi, kerugian keuangan negara, rusaknya moril karyawan serta dampak-dampak negatif lainnya.

\section{GONE Theory}

Teori yang juga membahas perilaku fraud dengan baik dikemukakan oleh Jack Bologne (1993). Teori ini dikenal sebagai GONE theory. Bologna dalam Soepardi (2006) menjelaskan faktor-faktor yang mendorong terjadinya kecurangan (fraud) meliputi:

1. greed (keserakahan), berkaitan dengan adanya perilaku serakah yang secara potensial ada di dalam diri setiap orang.

2. opportunity (kesempatan), berkaitan dengan keadaan organisasi atau instansi masyarakat yang sedemikian rupa sehingga terbuka kesempatan bagi seseorang untuk melakukan fraud terhadapnya.
3. needs (kebutuhan), berkaitan dengan faktorfaktor yang ibutuhkan oleh individu untuk menunjang hidupnya yang menurutnya wajar. exposure (pengungkapan), berkaitan dengan tindakan atau konsekuensi yang akan dihadapi oleh pelaku fraud apabila pelaku ditemukan melakukan fraud.

\section{Akuntansi Forensik}

Tuanakotta (2012) mengemukakan bahwa akuntansi forensik adalah penerapan disiplin akuntansi dalam arti luas, termasuk auditing, pada masalah hukum untuk penyelesaian hukum didalam atau di luar pengadilan. Akuntansi forensik dapat diterapkan di sektor publik maupun swasta, sehingga apabila memasukkan pihak yang berbeda, maka akuntansi forensik menurut Crumbley dalam Tuanakotta (2012) mengemukakan bahwa secara sederhana akuntansi forensik dapat dikatakan sebagai akuntansi yang akurat untuk tujuan hukum, yang tahan uji dalam kancah perseteruan selama proses pengadilan, dalam proses peninjauan yudisial atau tinjauan administratif.

$$
\text { Bologna dan Lindquisdt }
$$
mendefinisikan akuntansi forensik dan investigasi adalah aplikasi kecakapan finansial dan sebuah mentalitas penyelidikan terhadap isu-isu yang tidak terpecahkan, yang dijalankan dalam konteks aturan pembuktian. De Lorenzo (1993) mendefinisikan akuntansi forensik sebagai penerapan pengetahuan akuntansi dan keterampilan untuk masalah hukum, meskipun dalam lingkungan komersial yang kompleks saat ini makna dan penggunaan istilah ini jauh lebih luas. Tuanakotta (2012) mengemukakan di sektor publik (pemerintahan), tahap-tahap dalam seluruh rangkaian akuntansi forensik terbagi-bagi diantara 
Dinamika Sosial Budaya, Vol 19, No. 2, Desember 2017, pp 178-190

p-ISSN: $1410-9859 \&$ e-ISSN: $2580-8524$

http://journals.usm.ac.id/index.php/jdsb

berbagai lembaga. Juga ada lembaga swadaya masyarakat yang berfungsi sebagai pressure group seperti ICW, Pekat UGM, dan sebagainya. Di sektor publik maupun privat, akuntansi forensik berurusan dengan kerugian. Di sector publik ada kerugian negara dan kerugian keuangan negara sedangkan di sektor privat juga ada kerugian yang timbul karena cidera janji dalam suatu perikatan. Kerugian adalah titik pertama dalam Segitiga Akuntansi Forensik.

Titik kedua dalam Segitiga Akuntansi Forensik adalah perbuatan melawan hukum. Tanpa perbuatan melawan hukum, tidak ada yang dapat dituntut untuk mengganti kerugian dan titik ketiga dalam Segitiga Akuntansi Forensik adalah adanya keterkaitan antara kerugian dan perbuatan melawan hukum atau ada hubungan kausalitas antara kerugian dan perbuatan melawan hukum. Perbuatan melawan hukum dan hubungan kausalitas adalah ranahnya para ahli dan praktisi hukum, sedangkan perhitungan besarnya kerugian adalah ranahnya para akuntan forensik.

\section{Akuntansi Forensik terhadap Pendeteksian (Detektif) Fraud}

Berikut adalah gambaran secara garis besar pendeteksian kecurangan berdasarkan penggolongan fraud oleh ACFE dalam Miqdad (2008) yaitu:Kecurangan Laporan Keuangan (Financial Statement Fraud). Penyalahgunaan aset (Asset Misappropriation,),Korupsi (Corruption)

Dari Uraian diatas dapat dirumuskan hipotesis penelitian sebagai berikut :

Hipotesis 1 : Pemahaman terhadap akuntansi Forensik dapat mempengaruhi kendali religius.

\section{Sistem Pengendalian Intern}

Mulyadi \& Kanaka P (1998) berpendapat bahwa pengendalian intern adalah suatu proses yang dijalankan oleh dewan komisaris, manajemen dan personel lain, yang didesain untuk memberikan keyakinan memadai tentang pencapaian tiga golongan tujuan berikut:

1. Keandalan pelaporan keuangan

2. Kepatuhan terhadap hukum dan peraturan yang berlaku

\section{Efektivitas dan efisiensi operasi}

Theodorus M.Tuanakotta (1982), mengatakan pengendalian intern adalah meliputi rencana dan semua metode kebijaksanaan yang terkordinasi dalam suatu perusahaan untuk mengamankan harta kekayaannya, menguji ketepatan dan sampai seberapa jauh data akuntansi dapat dipercaya, manggalakkan efisiensi usaha dan mendorong ditaatinya kebijaksanaan yang telah digariskan. Dan Arens (2003:396) juga mengatakan suatu sistem pengendalian intern terdiri dari kebijakan dan proses yang dirancang untuk memberikan manajemen jaminan yang wajar bahwa perusahaan mencapai tujuan dan sasarannya.Sistem pengendalian intern adalah metoda yang digunakan untuk menjaga atau melindungi aktiva, menghasilkan informasi yang dapat dipercaya, memperbaiki efisiensi dan untuk melindungi kebijakan manajemen ( Krismadji, 2002:219). Menurut COSO dalam Tunggal (2010:232), pengendalian intern terdiri dari 5 komponen yang saling terkait yaitu :

1. Lingkungan pengendalian (control environtment) menetapkan corak suatu organisasi, mempengaruhi kesadaran pengendalian orang-orangnya. Lingkungan pengendaian merupakan dasar untuk semua 
Dinamika Sosial Budaya, Vol 19, No. 2, Desember 2017, pp 178-190

p-ISSN: $1410-9859 \&$ e-ISSN: 2580-8524

http://journals.usm.ac.id/index.php/jdsb

pengendalian intern, menyediakan disiplin dan struktur.

2. Penaksiran resiko (risk Assesment) adalah identifikasi entitas dan analisis terhadap resiko yang relevan untuk mencapai tujuannya, membentuk suatu dasar untuk menentukan bagaiman resiko harus dikelola.

3. Standar Pengendalian (control activities)adalah kebijakan dari prosedur yang membantu menjamin bahwa arahan manajemen dilaksanakan.

4. Informasi dan komunikasi (information and communication) adalah pengidentifikasian, pengungkapan, dan pertukaran informasi dalam suatu bentuk dari waktu yang memungkinkan orang melaksanakan tanggung jawab mereka. Sistem informasi mencakup sistem akuntansi, terdiri atas metode dan catatan yang dibangun untuk mencatat, mengolah, meringkas dan melaporkan transaksi entitas dan untuk memelihara akuntabilitas bagi aktiva, utang dan ekuitas. Komunikasi mencakup penyediaan suatu pemahaman tentang peran dan tanggung jawab individual berkaitan dengan pengendalian intern terhadap pelaporan keuangan.

5. Pemantauan (monitoring) adalah proses menentukan mutu kinerja pengendalian intern sepanjang waktu. Pemantauan mencakup penentuan desain dan operasi pengendalian yang tepat waktu dan pengambilan tindakan koreksi. Dari uraian diatas tentang pemahaman terhadap sistem pengendalian intern perusahaan klien dapat dirumuskan hipotesis penelitian sebagai berikut :

\author{
Hipotesis 2: Pemahaman Sistem Pengendalian \\ intern dapat mempengaruhi kendali \\ religius.
}

\section{Asimetri Informasi}

Dalam suatu organisasi atau perusahaan terdapat aturan yang menjadi dasar perilaku manajemen yang dibuat untuk mencegah terjadinya aktivitas menyimpang yang dapat merugikan perusahaan. Salah satu aturan dalam suatu perusahaan atau organisasi adalah aturan akutansi. Aturan akuntansi mengatur tentang pelaporan keuangan yang berpedoman pada PSAK yang dikeluarkan oleh IAI. Informasi yang tersedia dalam laporan keuangan sangat penting bagi investor dan manajemen sehingga harus dapat diandalkan. Sehingga dibutuhkan suatu aturan untuk menjaga keandalan informasi tersebut dan menghindari tindakan yang menyimpang yang dapat merugikan perusahaan atau organisasi.

Anthony dan Govindrajan (2001), menyatakan bahwa kondisi asimetri informasi muncul dalam teori keagenan (agency theory), yaitu principal (pemilik/atasan) memberikan wewenang kepada agen (manajer/bawahan) untuk mengatur perusahaan yang dimilikinya. Pendelegasian wewenang akan menyebabkan manajer sebagai pengelola perusahaan akan lebih mengetahui prospek dan informasi perusahaan sehingga menimbulkan ketidak seimbangan informasi antara manajer dengan pemilik yang disebut dengan asimetri informasi. Asimetri informasi antara manajer (agen) dan pemilik (principal) inilah yang dapat memberikan kesempatan kepada manajer untuk melakukan tindakan-tindakan kecurangan yang dapat menguntungkan dirinya. Selanjutnya Rahmawati dkk.(2006) dalam Adryani 
Dinamika Sosial Budaya, Vol 19, No. 2, Desember 2017, pp 178-190

p-ISSN: $1410-9859 \&$ e-ISSN: 2580-8524

http://journals.usm.ac.id/index.php/jdsb

mengemukakan beberapa kondisi perusahaan yang berkemungkinan besar memberikan kesempatan timbulnya asimetri informasi, yaitu perusahaanperusahaan yang sangat besar yang mempunyai penyebaran secara geografis, yang meiliki prosedur beragam, dan membutuhkan teknologi. Tipe asimetri Informasi. Menurut Jansen dan Meckling (1976) dalam Olyvia (2010) ada dua tipe asimetri informasi yaitu:

1. Adverse selection, Adverse selection adalah sejenis asimetri informasi dimana satu pihak atau lebih yang melangusungkan suatu transaksi usaha, atau transaksi usaha potensial memiliki informasi lebih atas pihak-pihak lain.

2. Moral Hazard, Moral hazard adalah jenis asimetri informasi dimana satu pihak atau lebih yang melangsungkan atau akan melangsungkan suatu transaksi usaha atau transaksi usaha potensial dapat mengamati tindakan-tindakan mereka dalam penyelesaian transaksi-transaksi mereka sedangkan pihakpihak yang lainnya tidak.

Dari uraian diatas tentang asimetri Informasi terhadap perusahaan klien dapat dirumuskan hipotesis penelitian sebagai berikut :

Hipotesis 3 : Asimetri informasi mempengaruhi kendali religius.

\section{Kompensasi}

Manusia bekerja selain bertujuan sebagai bentuk ibada, tetapi juga sebagi upaya memenuhi kebutuhan hidupnya. Untuk itulah seorang karyawan mulai menghargai kerja keras dan semakin menunjukkan loyalitas terhadap perusahaan dan karena itulah perusahaan memberikan penghargaan terhadap prestasi kerja karyawan yaitu dengan jalan memberikan kompensasi. Salah satu cara manajemen untuk meningkatkan prestasi kerja, memotivasi dan meningkatkan kinerja para karyawan adalah melalui kompensasi (Mathis dan Jackson, 2000 dalam Dito, 2010). Kompensasi penting bagi karyawan sebagai individu karena besarnya kompensasi mencerminkan ukuran karya mereka diantara para karyawan itu sendiri, keluarga dan masyarakat.

Kompensasi seringkali juga disebut penghargaan dan dapat didefinisikan sebagai setiap bentuk penghargaan yang diberikan kepada karyawan sebagai balas jasa atas kontribusi yang mereka berikan kepada organisasi (Dito, 2010). Selain itu dalam buku Malayu S.P. Hasibuan (2002) dalam Dito (2010) terdapat beberapa pengertian kompensasi dari beberapa tokoh. Menurut William B. Werther dan Keith Davis kompensasi adalah apa yang seorang pekerja terima sebagai balasan dari pekerjaan yang diberikannya. Baik upah per jam ataupun gaji periodic didesain dan dikelola oleh bagian personalia. Dan menurut Andrew F. Sikula kompensasi adalah segala sesuatu yang dikonstitusikan atau dianggap segai suatu balas jasa atau ekuivalen. Menurut Malayu S.P. Hasibuan (2002) dalam Dito (2010), tujuan pemberian kompensasi (balas jasa) antara lain adalah: Ikatan Kerja Sama, Kepuasan kerja, pengadaan efektif, motifasi, stabilitas karyawan, disiplin, pengaruh serikat kerja serta pangarug pemerintah.

Dari uraian diatas tentang kompensasi pelaksanaan pekerjaan audit dapat dirumuskan hipotesis penelitian sebagai berikut :

Hipotesis 4 : Kompensasi berpengaruh terhadap kendali religius 
Dinamika Sosial Budaya, Vol 19, No. 2, Desember 2017, pp 178-190

p-ISSN: $1410-9859 \&$ e-ISSN: 2580-8524

http://journals.usm.ac.id/index.php/jdsb

Nilai Religius

Religiusitas merupakan pernyataan seseorang mengenai kepercayaannya kepada Tuhan, yang ditandai dengan ketaatan dan semangat keagamaan. Semakin tinggi ketaatan dan semangat keagamaan, maka semakin kuat kepercayaannya kepada Tuhan, semakin tinggi religiusitasnya (Syukri, 2012). Religiusitas dipahami sebagai tingkat keimanan seseorang dalam menghayati dan mengamalkan ajaran ajaran agama yang dianutnya. Menurut Mangunwijaya (1999) ada perbedaan antara penghayatan agama dan religiusitas. Penghayatan agama lebih tertuju kepada aspek peraturan, hukum, organisasi, ritual, formalitas dan hubungan sosial antar penganutnya. Sementara religiusitas lebih pada esensinya yang menjadi sumber dan akar dari sikap dasar seseorang dalam hubungannya denagan Tuhan dan sesama, jadi lebih bersifat personal. Hal ini dipahami sebagai iman.

Dimensi religius menurut Ghozali (2002) bahwa dalam psikologi sosial dikenal adanya perbedaan antara knowing (kognitif), feeling (afektif), dan doing (behavior). Kategori psikologi sosial ini banyak digunakan untuk melihat tiga komponen religiusitas. Sedangkan menurut Glock dan Stark (dalam Ancok dan Suroso, 2011) ada lima dimensi nilai religius, yaitu: Dimensi idiologi ( religious belief/ the ideological dimensions), dimensi ritualistik (religious practice, the ritualistic dimensions), dimensi penghayatan (religious feeling/ the experiential dimensions), dimensi intelektual ( religious knowledge/ the intellectual dimensions), dan dimensi konsekuensial ( religious effect/ the consequential dimensions)
Dari uraian diatas tentang Kendali religius dapat dirumuskan hipotesis penelitian sebagai berikut :

Hipotesis 5 : Kendali religius berpengaruh terhadap pengungkapkan Fraud Akuntansi pada saat pelaksanaan audit.

\section{METODE PENELITIAN}

\section{Populasi dan Sampel Penelitian}

Populasi adalah gabungan dari seluruh elemen yang berbentuk peristiwa, hal atau orang yang memiliki karakteristik yang serupa yang menjadi pesat perhatian seorang peneliti karena itu dipandang sebagai sebuah semesta penelitian (Ferdinand,2011). Populasi dalam penelitian ini adalah auditor pada kantor akuntan publik di Jawa Tengah yang terdaftar pada direktori IAPI (Institut Akuntan Publik Indonesia). Sampel dari penelitian ini yaitu auditor yang melaksanakan pekerjaan audit.

\section{Jenis dan Sumber Data}

Jenis data yang digunakan dalam penelitian ini adalah data primer yang dikumpulkan melalui pengiriman kuisioner pada responden. Sumber data adalah pendapat dan persepsi dari personil auditor yang melaksanakan proses audit. Personil tersebut adalah auditor dilingkungan KAP di Jawa Tengah.

\section{Metode Analisis Data}

\section{Uji Statistik Deskriptif}

Dalam penelitian ini statistik deskriptif digunakan sebagai teknik analisis dengan tujuan untuk menjelaskan atau memberikan informasi demografi responden penelitian (tingkat pendidikan, dan lama bekerja) serta deskripsi mengenai variabel penelitian. Menurut Ghozali (2006), statistik 
Dinamika Sosial Budaya, Vol 19, No. 2, Desember 2017, pp 178-190

p-ISSN: 1410-9859\& e-ISSN: 2580-8524

http://journals.usm.ac.id/index.php/jdsb

deskriptif memberikan gambaran atau deskripsi suatu data yang dilihat dari nilai rata-rata (mean), standar deviasi, varian, maksimum dan minimum.

Pengujian hipotesis penelitian dilakukan dengan pendekatan Structural Equation Model (SEM) dengan menggunakan software Partial Least Square (PLS). PLS adalah model persamaan struktural (SEM) yang berbasis komponen atau varian (variance). Menurut Ghozali (2008) PLS merupakan pendekatan alternatif yang bergeser dari pendekatan SEM berbasis covariance menjadi berbasis varian. SEM yang berbasis kovarian umumnya menguji kausalitas/teori, sedangkan PLS lebih bersifat predictive model. Menurut Ghozali (2008) tujuan PLS adalah membantu peneliti untuk tujuan prediksi. Model formalnya mendefinisikan variabel laten adalah linear agregat dari indikatorindikatornya. Hasilnya adalah residual variance dari variabel dependen (keduanya variabel laten dan indikator) diminumkan. Estimasi parameter yang didapat dengan PLS dapat dikatagorikan menjadi tiga. Pertama, adalah weight estimate yang digunakan untuk menciptakan skor variabel laten. Kedua, mencerminkan estimasi jalur (path estimate) yang menghubungakan variabel laten dan antar variabel laten dan blok indikatornya (loading). Ketiga adalah berkaitan dengan mean dan lokasi parameter (nilai konstan regresi) untuk indikator dan variabel laten. Untuk memperoleh ketiga estimasi ini, PLS menggunakan proses iterasi tiga tahap dan setiap tahap iterasi menghasilkan estimasi. Tahap pertama, menghasilkan weight estimate, tahap kedua mengahsilkan estimasi untuk inner model dan outer model, dan tahap ketiga menghasilkan estimasi means dan lokasi (konstanta).

\section{HASIL PENELITIAN DAN PEMBAHASAN}

Pembahasan pada bab ini adalah hasil dari studi lapangan untuk memperoleh data dengan menggunakan kuesioner untuk mengukur enam variabel pokok dalam penelitian ini, yaitu pemahaman akuntansi forensik, sistem pengendalian intern, asimetri informasi, kompensasi, kendali religius dan fraud akuntansi. PLS merupakan pendekatan alternatif yang bergeser dari pendekatan SEM berbasis covariance menjadi berbasis varian.

\section{Analisis Data}

Teknik pengolahan data dengan menggunakan metode SEM berbasis Partial Least Square (PLS) memerlukan 2 tahap untuk menilai Fit Model dari sebuah model penelitian (Ghozali, 2006). Tahaptahap tersebut adalah sebagai berikut :

\section{Menilai Outer Model atau MeasurementModel}

Output merupakan salah satu yang disajikan untuk beberapa estimasi penelitian. Beberapa hasil yang ditampilkan antara lain koefisien determinasi, reliabilitas instrumen, validitas diskriminan dan lain lain. Penggunaan teknik analisa data dengan WarpPLS untuk menilai outer model yaitu Convergent Validity, Discriminant Validity dan Composite Reliability. Convergent validity dari model pengukuran dengan refleksif indikator dinilai berdasarkan korelasi antara item score/component score yang diestimasi dengan Soflware PLS. Ukuran refleksif individual dikatakan tinggi jika berkorelasi lebih dari 0,70 dengan konstruk yang diukur.

\section{Mengevaluasi Reliability dan Average Variance $\operatorname{Extracted}(A V E)$}


Dinamika Sosial Budaya, Vol 19, No. 2, Desember 2017, pp 178-190

p-ISSN: 1410-9859\& e-ISSN: 2580-8524

http://journals.usm.ac.id/index.php/jdsb

Kriteria validity dan reliabilitas juga dapat dilihat dari nilai reliabilitas suatu konstruk dan nilai Average Variance Extracted (AVE) dari masingmasing konstruk. Konstruk dikatakan memiliki reliabilitas yang tinggi jika nilainya 0,70 dan AVE berada diatas 0,50 . Dapat disimpulkan bahwa semua konstruk memenuhi kriteria reliabel. Hal ini ditunjukkan dengan nilai composite reliability di atas 0,70 dan AVE diatas 0,50 sebagaimana kriteria yang direkomendasikan.

\section{Pengujian Model Struktural (InnerModel)}

Pada prinsipnya penelitian ini menggunakan 5 buah variabel yang dipengaruhi oleh variabel lainnya yaitu variabel pengungkapan fraud akuntansi (PfrAk) yang dipengaruhi oleh Kendali religius (KRgs) yang dipengaruhi oleh Pemahaman terhadap akuntansi forensik (PakF), variabel sistem pengendalian intern (SPI), variabel Asimetri informasi (AsIN), variabel Kompensasi (Komp).

\section{PengujianHipotesis}

Signifikansi parameter yang diestimasi memberikan informasi yang sangat berguna mengenai hubungan antara variabel-variabel penelitian. Dasar yang digunakan dalam menguji hipotesis adalah nilai yang terdapat pada output result for inner weight.

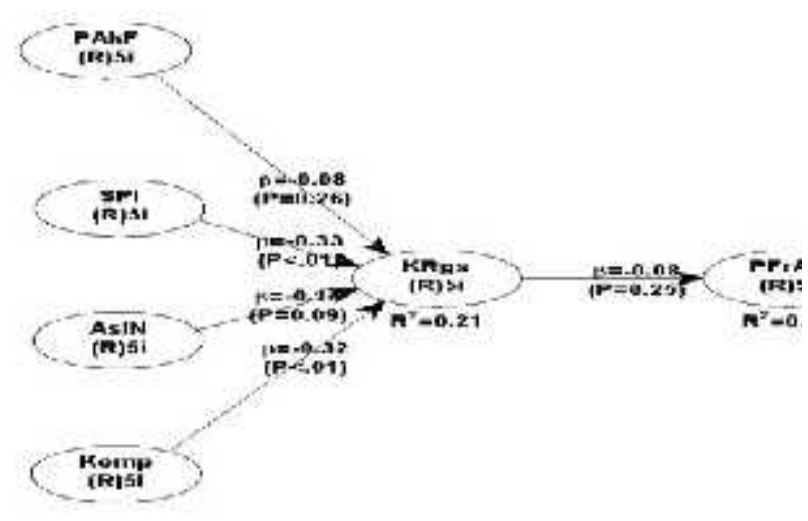

Dalam PLS pengujian secara statistik setiap hubungan yang dihipotesiskan dilakukan dengan menggunakan simulasi. Dalam hal ini dilakukan metode bootstrap terhadap sampel. Pengujian dengan bootstrap juga dimaksudkan untuk meminimalkan masalah ketidaknormalan data penelitian. Hasil pengujian denganbootstrapping dari analisis PLS adalah sebagai berikut :

Hipotesis 1 : Pemahaman terhadap akuntansi Forensik dapat mempengaruhi kendali religius.

Hasil pengujian hipotesis menunjukkan bahwa hubungan variabel pemahaman terhadap akuntansi forensik dengan kendali religius menunjukkan nilai koefisien sebesar dengan nilai $\mathrm{t}$ sebesar 5.263 . Nilai tersebut lebih besar dari t tabel $(1,960)$. Hasil ini berarti pemahaman terhadap akuntansi forensik dengan kendali religius sesuai dengan hepotesis HaliniberartiHipotesis1diterima.

Hipotesis 2 : Pemahaman Sistem Pengendalian intern dapat mempengaruhi kendali religius.

Hasil pengujian hipotesis menunjukkan bahwa hubungan variabel pemahaman sistem pngendalian intern dengan kendali religius menunjukkan nilai koefisien sebesar dengan nilai $\mathrm{t}$ sebesar 3.523 . Nilai tersebut lebih besar dari t tabel $(1,960)$. Hasil ini berarti pemahaman sistem pengendalian intern dengan kendali religius sesuai dengan hepotesis HaliniberartiHipotesis2diterima.

Hipotesis 3 : Asimetri informasi mempengaruhi kendali religius.

Hasil pengujian hipotesis menunjukkan bahwa hubungan variabel Asimetri informasi dengan kendali religius menunjukkan nilai koefisien sebesar dengan nilai t sebesar 4.778 . Nilai tersebut lebih besar dari $t$ tabel $(1,960)$. Hasil ini berarti 
Dinamika Sosial Budaya, Vol 19, No. 2, Desember 2017, pp 178-190

p-ISSN: $1410-9859 \&$ e-ISSN: 2580-8524

http://journals.usm.ac.id/index.php/jdsb

asimetri informasi dengan kendali religius sesuai dengan hepotesis HaliniberartiHipotesis3diterima.

Hipotesis 4 : Kompensasi berpengaruh terhadap kendali religius

Hasil pengujian hipotesis menunjukkan bahwa hubungan variabel kompensasi dengan kendali religius menunjukkan nilai koefisien sebesar dengan nilai t sebesar 1.541. Nilai tersebut lebih kecil dari $\mathrm{t}$ tabel $(1,960)$. Hasil ini berarti kompensasi dengan kendali religius tidak sesuai dengan hepotesis HaliniberartiHipotesis4 ditolak.

Hipotesis 5: Kendali religius berpengaruh terhadap pengungkapkan Fraud Akuntansi pada saat pelaksanaan audit.

Hasil pengujian hipotesis menunjukkan bahwa hubungan variabel kendali religius dengan pengungkapan fraud akuntansi menunjukkan nilai koefisien sebesar dengan nilai $\mathrm{t}$ sebesar 0.485 . Nilai tersebut lebih kecil dari t tabel ( 1,960). Hasil ini berarti kendali religius dengan pengungkapan fraud akuntansi, tidak sesuai dengan hepotesis $\mathrm{Hal}$ ini berarti Hipotesis 5 ditolak.

\section{KESIMPULAN}

Penelitian ini bertujuan untuk menganalisis pengaruh pemahaman terhadap akuntansi forensik, sistem pengendalian intern, asimetri informasi dan kompensasi terhadap kendali religius dan variabel kendali religius terhadap pengungkapan fraud akuntansi. Berdasarkan analisis dan pembahasan pada bagian sebelumnya, maka dapat ditarik kesimpulan sebagai berikut :

1. Variabel pemahaman terhadap akuntansi forensik, sistem pengendalian intern, asimetri infoemasi berhubungan dengan kendali religius

2. Variabel kompensasi tidak berpengaruh terhadap variabel kendali religius dan variabel kendali religius tidak mempunyai pengaruh terhadap variabel pengungkapan fraud

akuntansi

\section{Keterbatasan}

Pelaksanaan penelitian masih memiliki beberapa keterbatasan yaitu :

1. Kuesioner yang disampaikan kepada responden tidak semua kembali pada peneliti. Dan pengisian kuesioner cenderung asal mengisi.

2 Setiap indikator dari masing-masing variabel laten dalam penelitian ini masih memiliki nilai loading factor yang tidak paling besar dibanding nilai loading jika dihubungkan dengan variabel laten lain. Hal ini menunjukkan bahwa variabel laten masih memiliki pengukur berkorelasi tinggi dengan konstruklainnya.

\section{Saran}

Berdasarkan keterbatasan dalam penelitian ini, diharapkan Penelitian selanjutnya hendaknya perlu dilakukan uji pra-sampling kuesioner, karena dalam penelitian ini masih terdapat indikatorindikator yang bersifat ganda yaitu satu indikator dapat mengukur duavariabel.

\section{DAFTAR PUSTAKA}

Albrecht, W. Steve, Albrecht, Chad O., Albrecht, Conan C., \& Zimbelman, Mark.F., 2011.Fraud Examination.4th Edition. USA: South-Westem Cengage Learning. Association of Certified Fraud Examiners, 2008. Report to Nation on Occupational Fraud \& Abuse. Texas : The Association of Certified Fraud Examiners, Inc.

Association of Certified Fraud Examiners, 2016.Fraud Examiners Manual (International Edition). Texas: The Association of Certified Fraud Examiners, Inc.

Amin Widjaya. 1992. Pemeriksaan Kecurangan (Fraud Auditing). Rineka Cipta: Jakarta 
Dinamika Sosial Budaya, Vol 19, No. 2, Desember 2017, pp 178-190

p-ISSN: $1410-9859 \&$ e-ISSN: $2580-8524$

http://journals.usm.ac.id/index.php/jdsb

Anthony.N. Robert dan Govindrajan Vijay.2001. Managemen Control System.Buku 2. Saemba Empat: Jakarta.

Arifiyani, Hesti Arlich. 2012. Pengaruh Pengendalian Intern, Kepatuhan dan Kompensasi Manajemen Terhadap Perilaku Etis Karyawan. Jurnal Nominal Vol.1.No1.Tahun 2012. FE UNY: Yogyakarta.

Bologna \& Linquisdt, 1995. Fraud Auditing and Forensic Accounting: New Tolls and Techniques. New York, USA : John Wiley \& Sons, Inc.

Cressey, 1953. Other People Money, Study in the Social Psichology of Embezzlement. Montclain, JN: Patterson Smith.

Crumbley, 2005.Forensic and Investigative Accounting. USA. CCH Group: ISBN 0808013653,2005.

COSO (n.d.), Committee of Sponsoring Organization of Treadway Commission. Internal Control -Integrated Framework, AICPA, New York, NY.

COSO ERM (2004), Committee of Sponsoring Organization of Treadway Commission. Enterprise Risk Management - Integrated Framework, AICPA, New York, NY.

Fauzan, Purnamasari dan Gunawan, 2015.Pengaruh Akuntansi Forensik dan Audit Investigatif terhadap Pengungkapan Fraud (Studi Kasus pada Badan Pengawasan Keuangan dan Pembangunan Perwakilan Jawa Barat).Prosiding Akuntansi. ISSN: 24606561.

Friskila.Monigka.2010. Pengaruh Ketaatan akuntansi, Sistem Pengendalian Intern, Moralitas Manajemen dan Kesesuaian Kompensasi Terhadap Kecenderungan Kecurangan Akuntansi (Studi Empiris pada Perusahaan BUMN di Kota Padang). FE UNP : Padang

Ghozali, Imam. 2007. Aplikasi Analisis Multivariate dengan Program SPSS, Cetakan IV. Semarang: Badan Penerbit Universitas Diponegoro, Semarang.

Hopwood, W. S. Leiner, J. J. \& Young, G. R. 2008.Forensic Accounting. New York, : McGraw - Hill/ Irwin Companies.

Howard \& Sheetz, 2007.Forensic Accounting and Fraud Investigation for Non-Experts. New York, USA : John Wiley \& Sons, Inc.

Ikatan Akuntan Indonesia. 2001. Standar Pforesional Akuntan Publik. Salemba Empat: Jakarta.Irditkesad, Kutiyono. Fraud (kecurangan): Apa dan Mengapa
Ikatan Akuntan Indonesia, 2002. Standar Akuntansi Keuangan. IAI - Kompartemen Akuntan Publik, Jakarta.

Koroy, Tri Ramaraya. 2008. Pendeteksian Kecurangan (Fraud) Laporan Keuangan Oleh Auditor Eksternal.Jurnal Akuntansi dan Keuangan. Vol.1

Okoye and Gbegi, 2013. Forensic Accounting: A Tool for Fraud Detection and Prevention in the Public Sector. (A Study of Selected Ministries in Kogi State).International Journal of Academic Research in Business and Social Sciences. Vol.3, No.3, March 2013. ISSN:2222-6990.

Rahmawati.2006. Pengaruh Asimetri Informasi Terhadap Praktek Manajemen Laba Pada Perusahaan Perbankan Publik yang Terdaftar di BEJ. SNA IX: Padang.

Santoso, 2011.Efisiensi dan Efektivitas Pengelolaan Keuangan Daerah di Kabupaten Ngawi.Tesis.Surakarta : FEUniversitas Sebelas Maret.

Sihombing, 2014. Analisis Fraud Diamond Dalam Mendeteksi Financial Statement Fraud : Studi Empiris pada Perusahaan Manufaktur yang terdaftar di Bursa Efek Indonesia (BEI) Tahun 2010-2012. Diponegoro Journal of Accounting Vol.03, No.2, 2014.

Swarna, 2012.Penerapan Akuntansi Forensik dan Audit Investigasi dalam Mendeteksi Fraud di Lingkungan Digital.Medan : Fakultas Ekonomi-Universitas Sumatera Utara.

Tuanankotta, Theodorus.M. 2007. Akuntansi Forensik dan Audit Investigasi Seri Departemen akuntansi. FE UI : Jakarta.

Tuanakotta, 2009.Menghitung Kerugian Keuangan Negara dalam Tindak Pidana Korupsi. Jakarta: Salemba Empat.

Tuanakotta, 2012.Akuntansi Forensik dan Audit Investigatif. Jakarta: Edisi 2, Salemba Empat.

Willopo. 2006. Analisis Faktor-Faktor Yang Berpengaruh Terhadap Kecenderungan Kecurangan Akuntansi Studi Pada Perusahaan Publik SNA IX : Padang.

Yelly, Anggraini. 2008. Pengaruh Asimetri Informasi \& Ukuran Perusahaan Terhadap Rekayasa Laporan Keuangan pada Perusahaan yang Terdaftar di BEI.

Zimbelman, Mark. F., Albrecht, Conan C., Albrecht, W. Steve, \& Albrecht, Chad O., 2014.Akuntansi Forensik (Forensik Accounting). Edisi Keempat. Jakarta : Salemba Empat,Cengage Learning Asia Pte Ltd. 